\title{
Will Indonesia be Successful in Reducing its Greenhouse Gas Emissions with REDD+?: the Threat of Organizational Fragmentation
}

\author{
Medrilzam, Paul Dargusch and John Herbohn \\ School of Agriculture and Food Sciences \\ The University of Queensland, Brisbane 4072, Australia
}

\begin{abstract}
REDD+ schemes are likely to be important components of climate change mitigation strategies for developing countries in a post-Kyoto framework. Many tropical forest countries have been preparing their REDD+ structures in anticipation of the requirements for REDD+ investment. Indonesia, as one of the main REDD+ supporters, is struggling to establish its REDD+ governance framework and REDD+ infrastructure while waiting for the REDD+ mechanism to be ready for implementation at the global level. Demonstration activities are being conducted and several policy documents and regulations have been released since 2007. However, some issues remain outstanding, including organization fragmentation, raising concerns as to whether a REDD+ scheme can be implemented to effectively reduce Indonesia's greenhouse gas emissions. This paper examines Indonesia's efforts in preparing the REDD+ scheme through evaluations of climate change and REDD+ policy products from various government organizations. Descriptive analysis involving observations on various climate change and REDD+ products is used to reveal complexities that exist within the relationship among government organizations. This paper exposes six lessons learned from Indonesia's experience and concludes that reduction of organization fragmentation on REDD+ is to be the highest priority action for Indonesia in the short term. With a clear organization framework, REDD+ implementation will be easier to manage and potentially increase investor confidence in REDD+ projects in Indonesia.
\end{abstract}

Keywords: climate change policy, organizational fragmentation, UNFCCC

\section{INTRODUCTION}

As part of global climate change mitigation efforts, in 2007 the United Nations Framework Convention on Climate Change (UNFCCC) proposed a new scheme called Reducing Emissions from Deforestation and forest Degradation Plus (REDD+) scheme. REDD+ is an international payment for environmental services (PES) instrument that requires developed countries to compensate developing countries for their efforts to reduce their greenhouse gas emissions in the forestry sector. It is 
intended that REDD+ be fully implemented in a post-2012 framework (the second commitment period of the Kyoto Protocol). The symbol '+' indicates that the scheme's scope is broader than just avoiding deforestation and reduced forest degradation as was originally proposed; it also includes conservation of forest carbon stocks, sustainable management of forests and enhancement of forest carbon stocks (UNFCCC, 2010). The REDD+ scheme has become a topical issue for many tropical forest countries because the scheme has created opportunities for developing countries to obtain substantial support from developed countries while carrying out forest conservation and sustainable forest management (Clements, 2010). Developing countries expect to be paid by developed countries for their forest environmental services through the REDD+ mechanism after the first Kyoto Protocol commitment period finishes at the end of 2011 (Angelsen et al., 2009; Clements, 2010). On the other hand, developed countries consider REDD+ a relatively low-cost option to offset their greenhouse gas (GHG) emissions in order to ensure industrial and economic survival (RRI, 2009). Even though there have been discussions about whether REDD+ will bring benefits to all countries, heads of state agreed in the Copenhagen Accord in 2009 that REDD+ will be one of the post-2012 climate change mitigation options. Furthermore, the latest United Nations Framework Convention on Climate Change (UNFCCC) negotiations at Cancun in December 2010 concluded that REDD+ is part of global mitigation actions. However, to date there has been no clear agreement on how REDD+ will be implemented. The REDD+ negotiations under the UNFCCC will continue and detailed agreements will depend on the result of other topics of negotiation including emission reduction targets by developed countries and the overall UNFCCC financial scheme after 2012.

Many tropical forest countries are preparing to be ready for the anticipated REDD+ implementation. Indonesia - one of the major tropical forest countries with $80 \%$ of its greenhouse gas emissions from the forestry sector - has paid considerable attention to development of the REDD+ concept. About 29 REDD+ demonstration projects are being developed and these are expected to provide input and guidance for REDD+ implementation in Indonesia (Wertz-Kanounnikoff and Kongphan-apirak, 2009). Political objectives were outlined by the Indonesian President, Soesilo Bambang Yudoyonoin, his speech at the G20 meeting in 2009, including that Indonesia will reduce its greenhouse gas emissions by $26 \%$ to $41 \%$ by 2020 . This ambitious objective has targeted the forestry sector as the largest sectoral greenhouse gas emitter in Indonesia. However, despite this strong political commitment, the forestry sector in Indonesia has been struggling to improve its forest conservation and production management for the last 30 years, and there are still many challenges that could threaten potential future REDD+ investments. One important challenge is the establishment of a forestry-climate change organizational and governance framework that could address the requirements of the REDD+ scheme. According to the Indonesia Forestry Law of 1999, the Ministry of Forestry has full authority to manage forest areas throughout Indonesia. However, the manner in which the Ministry of Forestry manages forest areas is often exclusive and closed to other institutions. Considering the comprehensiveness of REDD+ objectives - which include greenhouse gas emissions reduction, economic improvement, biodiversity protection, and forest conservation and management improvement - the involvement of non-forestry 
organizations is necessary to support positive outcomes. Therefore, there is a need for an appropriate organizational arrangement between forestry and non-forestry organizations in the current government and non-government structures before REDD+ is implemented in Indonesia.

The principal research question addressed in this paper relates to how Indonesia might best cope with the complexity of government and non-government organizational frameworks in managing REDD+ preparation and implementation. The paper uses descriptive analysis based on the direct experience and involvement of the lead author in Indonesia's REDD+ debate, including observations and analysis of some of Indonesia's policy products and relevant literature. The paper describes the present state of REDD+ policy development in Indonesia and discusses various products of climate change and REDD+ policies released by several institutions from 2007-2011. The paper also provides an analysis of the REDD+ institutional development framework to reveal potential threats of organizational fragmentation in Indonesia.

\section{THE CURRENT STATUS OF REDD+ NEGOTIATIONS}

REDD+ negotiations under the UNFCCC have been discussed in several negotiation tracks ${ }^{1}$. In the 15th Conference of Parties to the UNFCCC (COP15) at Copenhagen in 2009, at least three major tracks were used: the Copenhagen Accord, the Ad Hoc Working Group on Long-term Cooperative Actions (AWGLCA) and the Subsidiary Body for Scientific and Technological Advice (SBSTA). While the first track is not a formal process within the UNFCCC forum (but rather was a political

${ }^{1}$ UNFCCC negotiations are divided into six negotiation tracks: COP, COP/MOP, SBSTA, SBI, AWGKP and AWGLCA. The COP (Conference of Parties) is the highest decision body involving all members of the UNFCCC, while COP/MOP (Conference of Parties serving Meeting of Parties) is the highest decision body excluding the USA to discuss all related matters on the Kyoto Protocol implementation. The SBI (Subsidiary Body for Implementation) and SBSTA (Subsidiary Body of Science and Technical Advice) are technical bodies and serve the COP and COP/MOP. Both aim to facilitate all discussions and negotiations including preparing draft decisions for the COP and COP/MOP. The SBI focuses on the UNFCCC administration, technology transfer, funding arrangement (SBI), reporting and capacity building, while the SBSTA focuses its negotiation on scientific and methodological aspects. The AWGKP (Ad Hoc Working Group on the Kyoto Protocol) and the AWG-LCA (Ad Hoc Working Group on Long-term Cooperative Action) are two bodies established by the COP and the COP/MOP UNFCCC to prepare necessary actions for the post-First Kyoto Protocol period that will be completed in 2012. While the AWGKP bases its negotiation process on the continuation of the Kyoto Protocol including the emission reduction target by developed countries, the AWGLCA bases its negotiation process on the effort to increase the effectiveness of the UNFCCC convention in the post 2012 period. Currently, REDD+ negotiations are included as part of AWGLCA and SBSTA track. 
statement negotiated by the Heads of States), the last two are formal negotiation tracks established by UNFCCC decisions. In COP16 at Cancun 2010, the UNFCCC consistently applied its own internal negotiation mechanism and used only the AWGLCA and SBSTA negotiation tracks.

COP15 finished with only the lowest level of multilateral agreement on the Copenhagen Accord: 'take note'. The Accord produced no binding agreement, no ambitious targets by developed countries, no voluntary actions committed to by developing countries, and no agreed financial arrangement. Even though some world leaders from both developed and developing countries said that there was a positive result from the Copenhagen Accord, those statements were arguably only made to cover up the failure of national leaders to move the climate policy framework forward. Many NGOs and scientists said that COP15 of the UNFCCC at Copenhagen failed to deliver the expected outcomes of protecting current and future generations from global impact of climate change.

Arguably, the only positive result of the talks at COP15 was the REDD+ negotiations. Despite the important topics of these discussions (including the REDD+ target, funding commitments and safeguarding mechanism) being swept away by the breaking down of the new post-2012 climate change framework, the REDD negotiations seem to have had more success than other components of the negotiations. In the Copenhagen Accord, it is clearly stated that all world leaders recognize the importance of REDD+ and its mechanism to reduce carbon emissions and to absorb carbon from the atmosphere. This was a small step to ensure that REDD+ is part of the future binding international climate change agreement that was hoped to be achieved at COP17 in South Africa in 2011 or at the subsequent COP18 in 2012.

In COP16 at Cancun in 2010, the UNFCCC concluded its negotiations on several aspects of REDD+, including the scope of REDD+ (reducing emissions from deforestation; reducing emissions from forest degradation; conservation of forest carbon stocks; sustainable management of forests; enhancement of forest carbon stocks), some necessary means (development of the action plan; reference emission levels; forest monitoring systems) to implement it, a REDD+ safeguarding mechanism and some guidance for the SBSTA to follow at COP17 in 2011. However, some important aspects of REDD+ implementation were left undecided in Cancun, including financing of REDD+ investments (market or non-market funding), methodology, and institutional frameworks. Nonetheless, the UNFCCC has restored confidence to move forward with climate negotiations after the disappointing result at Copenhagen. It is hoped that COP17 in Durban, South Africa in 2011 will conclude all REDD+ negotiations and resolve issues undecided in Cancun, even though this will depend on other aspects of the negotiations, particularly the financing mechanisms and emission cuts by developed countries.

\section{COMPLEXITY OF CLIMATE CHANGE POLICY PRODUCTS AND ORGANIZATIONAL FRAGMENTATION IN INDONESIA}

Indonesia has actively promoted a climate change agenda since the Rio Declaration and establishment of the UNFCCC in 1992. Indonesia ratified the 
UNFCCC in 1994 and has been a Party to the Kyoto Protocol since 2004. In 2005 at the G77+ China meeting at COP11 in Montreal, Indonesia was the first nation to support PNG's proposal on avoiding deforestation, which eventually emerged as REDD ${ }^{2}$. Since then, Indonesia has actively encouraged all parties to put a REDD+ agenda into the post-2012 framework as a mitigation option that can be used by both developed and developing countries. In 2007, Indonesia successfully hosted COP13 in Bali and produced the Bali Action Plan, which ensured the integration of REDD+ into a post-2012 climate policy framework (UNFCCC, 2007). Indonesia is still pushing the REDD+ agenda in the international context, not only within the UNFCCC multilateral framework, but also through bilateral cooperation.

Along with its international actions, Indonesia is currently preparing its REDD+ readiness domestically to anticipate the agreement on the REDD+ scheme in the post2012 policy framework. REDD+ demonstration activities at sub-national (local and project) levels have been initiated by both the government and private sector, in order to examine how the REDD+ mechanism can be implemented effectively in Indonesia. However, to date these demonstration activities have produced no clear policy recommendations. Despite some projects being in early stages, many face operational challenges such as gaining the right to manage the forest conservation area from the Ministry of Forestry (e.g. the Rimba Raya project), securing financing (e.g. the Leuser REDD project) and operational implementation in the field (e.g. the KFCP project).Moreover, none of these demonstration activities are funded through the state budget. Most of them are funded by donor grants or private sources.

In spite of the lack of government contributions to REDD+ demonstration projects, the Indonesian Government has showed its commitment to prepare climate change policies including REDD+ policies since 2007 (Figure 1). Various government organizations have been involved and have competed with each other in preparing climate change policies. The description below reveals the detail of various climate change and REDD+ policy products produced by Indonesian government agencies from 2007 to June 2011. This paper recognizes two periods (2007-2009 and 2010mid 2011) of climate change and REDD+ policy development in relation to the role of government agencies.

\footnotetext{
${ }^{2}$ The first author was one of the Indonesian negotiators at this meeting.
} 


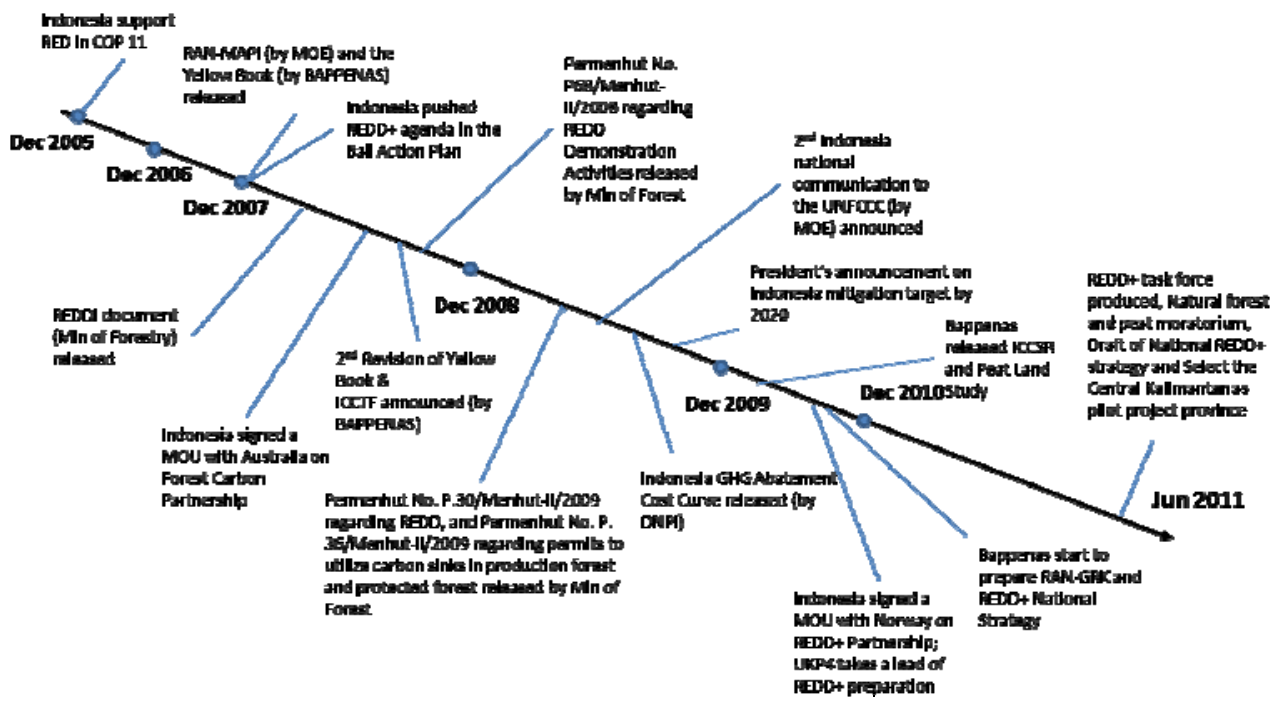

Figure 1. Timeline of Indonesian activities in preparing REDD from 2005 to December 2010

\section{Era 2007-2009: Competition among Government Organizations in Anticipation of REDD+ Agreement at Copenhagen}

The first initiative to include REDD+ policy in Indonesia's climate change policy framework began in 2007 led by the Ministry of Environment (MoE) and the National Development Planning Agency (BAPPENAS). As host of COP13 in Bali, the Indonesian Government wanted to show the world that Indonesia was committed and ready to combat global climate change by showcasing a domestic action plan integrated with wider development objectives. Two national documents, namely the National Action Plan on Climate Change Mitigation and Adaptation and The Yellow Book (National Development Planning - Indonesia's Response to Climate Change), were produced by the MoE and BAPPENAS respectively, prior to COP13 in 2007. However, neither document had received support from the Indonesian line ministries and donor countries ${ }^{3}$. There was much debate over the scientific and financial basis of the content of the MoE document. Moreover, some line ministries also questioned the authority of the MoE in coordinating and preparing the document. The document's content, which mostly revealed the development plan of sectoral ministries, was beyond the jurisdiction of the MoE. Meanwhile, the Yellow Book, which was intended to show how climate change issues are integrated into a development framework, lacked clarity of content and in the end had even less support from donor agencies.

3 This view is based on the first author's involvement during preparation of these documents. 
The most relevant REDD policy document in 2007-08 was produced by the International Forest Climate Alliance (IFCA), which represented a group of institutions coordinated by the Research and Development Unit of the Ministry of Forestry (Balitbang Dephut). The Balitbang Dephut received support from donor communities (the World Bank, the UK, Australia and Germany), and collaborated with NGOs to produce the REDD Indonesia document (REDDi). The REDDi examined aspects of REDD in detail including progress and outputs of studies on REDD methodologies, strategy, financial and market analysis and benefit payment distributions, including the Indonesia Road Map on REDD for 2007-12. Unfortunately, the REDDi had the same problem as the previous two documents, receiving little support from other government institutions resulting from the exclusivity of its preparation.

BAPPENAS initiated improvement of the Yellow Book in its second edition in 2008. At this stage BAPPENAS aligned the Yellow Book with a new funding initiative - the Indonesia Climate Change Trust Fund (ICCTF) - in which the forestry sector and REDD+ components were integrated. The second edition of the Yellow Book had great support by the line agencies and was received well by donor groups. Donor communities including Germany, the UK, France, Japan and Australia supported this initiative and provided direct assistance to BAPPENAS in further improving the Second Yellow Book through a few other studies such as the Indonesia Climate Change Sectoral Roadmap (ICCSR) (BAPPENAS, 2010) and Indonesia peatland study (CCROM, 2010). Unfortunately, the ICCSR failed to deliver the forestry sectoral road map because of the complexity of issues in the forestry sector. Meanwhile, the Indonesia peatland study produced a comprehensive view of the current state and proposed actions in Indonesia's peatlands. However, this peatland study was treated as an internal study by BAPPENAS and was not accepted broadly by the line ministries owing to the exclusivity of its preparation. Despite minimal weaknesses in both studies, they contributed substantially to development of the National Mid-term Development Plan 2010-2014, the first Indonesia national development plan which ranked climate change as one of Indonesia's top national development policy priorities.

During 2008-09, the Ministry of Forestry released a few regulations in relation to REDD initiatives in Indonesia including Permenhut No. P68/Menhut-II/2008 regarding REDD Demonstration Activities; Permenhut No. P.30/Menhut-II/2009 regarding REDD, and Permenhut No. P. 36/Menhut-II/2009 regarding permits to utilize carbon sinks in production forests and protected forests. The release of these three forestry regulations on REDD or carbon investment for both the compliance and voluntary markets offered contrasting opinions in supporting them. On the negative side, these regulations showed the lack of coordination among relevant ministries because complaints came from the other ministries. One strong reaction came from the Ministry of Finance over the REDD+ benefit distribution formulated in Permenhut No. P. 36/Menhut-II/2009 and called for a thorough review of the formula in this particular regulation. Even though the Ministry of Forestry had been trying to develop the regulations and policy processes on REDD+ transparently, many institutions felt that those efforts had been insufficient. Internal office politics and conflicts inside the Ministry of Forestry were also obvious when these three Permenhuts were released. 
Various Directorate Generals (DGs) competed with each other to release the regulations and establish their claim as the leading agency inside of the Ministry of Forestry. There was no clear policy stated by the Ministry of Forestry through which forest-climate change activities were to be coordinated. As REDD+ responsibilities were not clearly segregated according to the functions of several DGs, this arrangement inside the Ministry of Forestry had weakened the strength of the released regulations and potentially created confusion for REDD+ proponents.

On the positive side, the weaknesses of these regulations served as a lesson for the country, because REDD+ policy and regulation is not the exclusive concern of the forestry sector. The REDD+ scheme requires more support from other line ministries in the form of separate policies and regulations. A number of loopholes remain in these regulations, in particular on the determination of reference emission levels, scopes and financial mechanisms, including financial benefit distributions, indicates that REDD+ demands non-forestry regulations from other ministries. The regulation by the Ministry of Forestry only will not be sufficient to cover all REDD+ aspects because the Ministry of Forestry regulations can only rule out activities under its own jurisdiction. Besides, several aspects of REDD+ are beyond the Ministry of Forestry's authority. Unfortunately, an important suggestion during the limited public consultations to increase the level of those regulations to a Presidential Regulation had been neglected by the Ministry of Forestry. Nonetheless, these regulations showed that Indonesia has made efforts to include REDD+ in its national regulatory framework.

In 2009, the MoE and the National Council on Climate Change ${ }^{4}$ released two separate documents (The Second National Communication to the UNFCCC and Indonesia Greenhouse Gas Abatement Cost Curves respectively) reporting Indonesia's GHG emissions. These two reports were released before COP15 in 2009 and showed clear rivalry between the two institutions in coordinating climate change policy in Indonesia. Nonetheless, both reports showed that the forestry sector (including peatlands) is the major contributor to GHG emissions in Indonesia (DNPI, 2009; MoE, 2009). These reports also implicitly supported the claim of the WB-PEACE Report (2007) that Indonesia's GHG emission inventory is the third largest in the world if forestry and peat emissions are included in the total emission calculation.

The most controversial Indonesian policy on climate change was delivered by the President in his speech at the G20 meeting in Pittsburgh in 2009 prior to COP15 in Copenhagen. The President stated that Indonesia was committed to reducing its GHG emissions by $26 \%$ by 2020 using its own resources, and this figure might increase to $41 \%$ with support from the international community. There is still uncertainty about the origin of these figures because they were never discussed by Cabinet. As a result,

${ }^{4}$ The National Council on Climate Change (NCCC) was established by Presidential Regulation in 2008 to coordinate climate change policy in Indonesia. In its 'rivalry' with the MoE, the NCCC won the 'battle' as it usurped most of the MoE's authority in climate change policy areas, including the role of the UNFCCC Indonesia focal point and Designated National Authority (DNA) of the Clean Development Mechanism (CDM) under the Kyoto Protocol. The role of the former Minister of the MoE, who was appointed as the Executive Chairman of the NCCC by the President, smoothed the NCCC's path to take over these responsibilities from the MoE. 
these figures are not included in the new Indonesia National Mid-term Development Plan from 2010-14. However the forestry sector, as the biggest contributor to Indonesia's emissions, was instructed by the President to reduce its greenhouse gas emissions significantly, especially through peatland restoration and prevention of forest fires. The Ministry of Forestry responded positively to the President's instruction as demonstrated by its announcement of a 'one million tree' forest rehabilitation program nationally. Since the current Indonesian President's policy has been announced internationally, line related ministries have been trying to adapt this policy into their existing programs. However, the fragmentation of climate change and REDD+ policy document still existed. Each government organization was still doing their own approach because there was no credible institution appointed by the President in coordinating climate change and REDD+ in particular.

\section{Era 2010-2011: Cracking the REDD+ and Forestry Bureaucracy}

In 2010, the Government of Indonesia signed a Letter of Intent regarding 'Cooperation on reducing the greenhouse gas emissions from deforestation and forest degradation' with the Norwegian Government to secure a US\$1 billion grant within four years for REDD+ project implementation. The agreement states clearly that both countries will cooperate to reduce emissions from deforestation, forest degradation and peatland conversion through policy dialogues and REDD+ implementation in Indonesia. This partnership will be implemented in three phases (Preparation up to December 2010, Transformation during 2011-13, and Contribution for Verified Emission Reduction). The Indonesian Government claimed this assistance is evidence of strong international support for Indonesia to reduce its GHG emissions.

In terms of Indonesia's REDD+ organizational framework, the agreement above becomes an important milestone in the establishment of an ad hoc body under the President's office called 'Unit Kerja President bidang Pengawasandan Pengendalian Pembangunan' (UKP4) or 'Presidential Working Unit for Monitoring and Controlling of Development Implementation' to facilitate and coordinate the implementation of this agreement and REDD+ policy as a whole. The UKP4 is a feared institution for government cabinet organizations because it evaluates the performance of each organization on behalf of the President. Despite some suspicion about the involvement of a particular private group beyond the UKP4 to gain advantage from this US\$1 billion agreement ${ }^{5}$, the appointment seems to be a short cut for the President to speed up REDD+ implementation.

The President, through the UKP4, also established a REDD+ Task Force led by the Head of UKP4. The Task Force consists of representatives from the Ministry of Forestry, BAPPENAS, Ministry of Environment, and UKP4. This Task Force aims to take over of all REDD+ readiness preparation and coordination, including the REDD+ national strategy. The Task Force only worked until June 2011, and it eventually only produced a Moratorium on peatland and primary regulation, and a National REDD+ strategy draft, and selected the Central Kalimantan Province as the REDD+ pilot

\footnotetext{
${ }^{5}$ Report of independent evaluator (Caldecott et al., 2011) of this grant agreement reveals that special arrangements have been made by certain persons to appoint the UNDP and McKinsey and Co. to manage and implement this grant.
} 
project province. The Task Force still failed to deliver detailed aspects of REDD+ implementation such as a financial benefit distribution mechanism and the targeted amount of greenhouse gas emissions reduction from the Indonesia REDD+ scheme. Moreover, the Task Force handed over their tasks to a few future REDD+ bodies that will be established as recommended under the REDD+ national strategy draft. At present, the UKP4 still holds control over the REDD+ preparation in Indonesia.

In 2011, BAPPENAS also presented a new national action plan to reduce GHG emissions to the Cabinet Secretary (Rencana Aksi Nasionalmenurunkan Gas Rumah Kaca/RAN-GRK), replacing the old plan prepared by the MoE in 2007 at the request of the Coordinating Minister of Economy. To date, it is still unclear how policy recommendations for the forestry sector in this document will be implemented in accordance with the policies explained in the national REDD+ strategy.

\section{FRAGMENTATION OF REDD+ ORGANIZATION}

The above description of Indonesia REDD+ policy development experience has revealed organizational complexities in setting up REDD+ readiness and its future implementation. There are six lessons for policy makers to be taken from this experience:

First, even though the initial REDD+ initiative was designed to exclusively support the forestry sector in reducing its GHG emissions, it has been obvious that several non-forestry institutions in the Central Government level have been involved in REDD+ preparation. The involvement of these institutions cannot be avoided because the nature of REDD+ activities, in fact, must also embrace non-forestry aspects such as integration into development plans, financing schemes, land tenure, environmental management, and the drivers of deforestation and forest degradation (mostly from the agriculture sector). Furthermore, preparation of those non-forestry aspects is a prerequisite to be addressed prior to REDD+ implementation to ensure the achievement of the objectives of the REDD+ scheme.

Second, the above discussion also reveals that a country requires a long process of learning and preparing its institutional structure to be ready for REDD+ implementation. Preparing the national REDD + system is extremely complex (Saunders et al., 2008). Indonesia's experience shows that there has been no substantial progress on climate change and REDD+ policy development within four years (2007-2011) because institutions competed with each other and tried supersede one another. An integrated and cohesive plan with the support of a strong government leadership is required to prepare for REDD+ implementation.

Third, the institutional complexities of REDD+ preparation must be examined from a broad perspective recognizing the reason behind the actions of each institution. Before 2007, climate change policies were only a concern of the MoE. At that time, the forestry sector was mostly discussed under the Clean Development Mechanism (Afforestation and Reforestation Sector); this only evolved slightly as it received little attention of decision-makers. Instead, as shown in Figure 1, policies related to climate change and in particular REDD+ readiness have been emerging more rapidly since 2007. The existence of REDD+ regulations, funding mechanisms, demonstration projects and national forest carbon accounting systems are examples of rapid progress 
on REDD+ readiness policies and activities within the last three years. These are products of several government organizations in response to promising REDD+ aspiration according to the organization's own role and function (see Attachment 1). Unfortunately, those products are not closely linked to each other because they have been planned and developed separately. Each institution has maintained their separation and tended to take over the leadership and coordination of specific REDD+ initiatives.

Fourth, overlapping roles and functions of each institution in the climate change context are also obvious in Indonesia's case because each institution has a related role with climate change aspects (see Attachment 1 on agency roles and functions). Their original roles are broad enough to create wide-ranging interpretations in how they engage with climate change issues. As climate change is a multi-sectoral issue, there has been no clear arrangement about who takes a lead and how they work and support each other. Establishment of the Climate Change National Council (Dewan Nasional Perubahan Iklim, DNPI) in 2008, which aimed to strengthen coordination on policymaking decisions among government institutions, has not effectively improved the situation. Instead, the DNPI had encountered resistance from government ministries due to the appointment of several non-official persons who manage the technical secretariat and working groups, and also prepare policy decisions. The line ministries preferred to see that the policy decision-making process was solely managed by the government internally, and claimed that the existence of non-official persons in the Council has been inappropriate and reduced the capacity of each government agency to influence the decision.

Fifth, in the case of an appointment of an ad-hoc body to manage REDD+, the effort of the Presidential Office represented by UKP4 and the establishment of the REDD+ Task Force might perhaps result in contrary outcomes; reducing or increasing the fragmentation and disharmony of government coordination. The latter is a risk that the government has to bear in this decision. Dissatisfaction of some ministries because their roles have been taken over by the UKP4, and the involvement of nongovernment officials in current arrangements, could potentially repeat mistakes made by the DNPI and threaten the effectiveness of UKP4 and its REDD+ task force to overcome institutional fragmentation. Further, establishment of new ad hoc bodies for managing REDD+ preparation and implementation as suggested in the draft of the REDD+ National Strategy produced by the REDD+ Task Force, could potentially create further complexity in terms of coordination (Simamora, 2010) because existing government agencies have initiated activities to support REDD+ readiness. It is still unclear what the role of the existing government institutions will be in REDD+ implementation when these new bodies are established. Assigning one or more new institutions to undertake the whole or part of REDD+ preparations, in fact, indicates the inability of the President to manage his government structure, exposes lack of leadership and suggests incapability to manage climate change institutional complexities. The role of a strong coordinating institution under the existing government structure could perhaps help to reduce organizational fragmentation. At present, appointing an existing agency such as the Coordinating Ministry of Economy is conceivably more appropriate to coordinate the REDD+ scheme because this Ministry has a formal coordination role in the Cabinet. The other line ministries could 
assist the Coordinating Ministry of Economy in preparing the REDD+ scheme according to their own mandates. The appointment of ad-hoc institutions like UKP4 and the REDD+ Task Force to manage REDD+ preparations only reveals that internal coordination among government institutions is not functioning well.

Sixth, besides organizational fragmentation at the national level, the unclear roles of provincial and district governments could also potentially hamper the implementation of REDD+. Vertical organizational arrangement from central, provincial to district government is an important prerequisite for effective REDD+ implementation (Angelsen et al., 2008; Skutsch and VanLaake, 2008). Instead, several REDD+ demonstration projects have experienced coordination challenges with provincial and district governments because many strategic decisions in these projects were made by national government agencies without involving local decision makers. As the closest government level in project areas, the role of provincial and district governments is important while REDD+ project investors have to deal with local issues such as land tenure and the involvement of indigenous people (as required by the UNFCCC). Without the involvement of provincial and district governments, the sustainability of REDD+ investment could be threatened, because district governments will feel they have no obligation to support the projects, while at the same time national government agencies in Jakarta are unable to manage projects from afar.

\section{CONCLUSION}

The six lessons about organizational fragmentation discussed above indicate that clear leadership and credible institutional governance is a key to success in the REDD+ preparation process. Government organizational fragmentation in REDD+ preparation, which arises largely from the territorial and self-interested behaviour of individual ministries, and even separate agencies within the same ministry, results from the President's continuing lack of leadership, and the overlapping role and functions of government organizations. This problem could be overcome by appointing a neutral and credible existing government institution to force out external free riders and use the opportunity of billions of dollars of investment funding for REDD+. The appointment of UKP4 and its REDD+ Task Force, as an ad hoc body that reports directly to the President on the REDD+ Norway grant management, will potentially dominate the future of REDD+ institutional arrangements. Unless UKP4 and its REDD+ Task Force become permanent agencies overseeing future REDD+ management, there is a need for the government of Indonesia to improve its internal coordination and utilise its existing formal ministries rather than adding new ad hoc bodies with less clear responsibilities. The current active role of the Coordinating Ministry on Economics and BAPPENAS in preparation of the GHG Emission Reduction Plan (including the emission reduction in the forestry sector) is a positive initiative in shaping the integration of REDD + into the overall climate change policy; however, this must be supported by other line ministries and an improved internal capability including human resources. 


\section{ACKNOWLEDGMENTS}

This paper is the result of intensive discussions between the authors and relevant people engaging in REDD+ preparation in Indonesia. In particular, the authors would like to thank the Director of the Directorate of Forestry and Water Conservation Affairs and his staff, and the Directorate of Environmental Affairs staff of BAPPENAS for discussions about the latest developments in REDD+ policy in Indonesia.

\section{REFERENCES}

ANGELSEN, A. (ed.). 2008. Moving ahead with REDD: Issues, options and implications. CIFOR. Bogor, Indonesia.

ANGELSEN, A., BROCKHAUS, M., KANNINEN, M., SILLS, E., SUNDERLIN, W.D. and S. WERTZ-KANOUNNIKOFF (eds). 2009. Realising REDD+: National strategy and policy options. CIFOR. Bogor, Indonesia.

BAPPENAS (NATIONAL DEVELOPMENT PLANNING AGENCY). (2010). Indonesia Climate Change Sectoral Roadmap (ICCSR). The Government of Indonesia. Jakarta, Indonesia.

CALDECOTT, J., INDRAWAN, M., RINNE, P. and M. HALONEN. 2011. IndonesiaNorway REDD+ Partnership: First Evaluation of Deliverables. Gaia Consulting Ltd. in association with Creature Ltd, Helsinki.

CCROM. 2010. Reducing Carbon Emission from Indonesia's Peatlands. BAPPENAS, Jakarta, Indonesia.

CLEMENTS, T. 2010. Reduced expectations: the political and institutional challenges of REDD+.Oryx. 44(3): 309-310.

DNPI (NATIONAL COUNCIL ON CLIMATE CHANGE). 2009. Indonesia Greenhouse Gas Abatement Cost Curves. Jakarta.

MOE (MINISTRY OF ENVIRONMENT). 2009. The Second National Communication to the UNFCCC. Jakarta.

PEACE. 2007. Summary: Indonesia and Climate Change Working Paper on Current Status and Policies. Jakarta.

RRI (THE RIGHTS AND RESOURCES INITIATIVES). 2009. The End of the Hinterland: Forest, Conflict and Climate Change.Washington, DC.

SAUNDERS, J., EBELING, J. and R. NUSBAUMM. 2008. Reduced Emissions from Deforestation and Forest Degradation: Lessons from a Forest Governance Perspective. Ecosecurties and Proforest, Chatham House, Oxford.

SKUTSCHA, M. and P.E. VAN LAAKE. 2008. Redd as Multi-Level Governance in-themaking. Energy and Environment.19(6): 831-844

SIMAMORA, A. 2010. Planned REDD council to 'ease' ministry's job. The Jakarta Post. Jakarta.

UNFCCC (UNITED NATIONS FRAMEWORKS ON CLIMATE CHANGE CONVENTION). 2007. Bali Action Plan. Decision 1/CP.13.

WERTZ-KANOUNNIKOFF, S. and M. KONGPHAN-APIRAK. 2009. Emerging REDD+: A Preliminary Survey of Demonstration and Readiness Activities. CIFOR. Bogor, Indonesia. 
Attachment 1: Comparison of line institutions - role and functions related to REDD+

\begin{tabular}{|c|c|c|}
\hline Institution, role and functions & $\begin{array}{l}\text { Climate change and REDD+ } \\
\text { related products }\end{array}$ & Brief comments and/ analysis \\
\hline $\begin{array}{l}\text { Ministry of Forestry } \\
\text { General Roles and Functions: } \\
\text { Manage (conserve, protect and utilize) all forest } \\
\text { areas in Indonesia. } \\
\text { Roles and Functions in REDD+: } \\
\text { Prepare forestry policies and regulations in } \\
\text { relation to climate change; } \\
\text { Prepare all technical matters related to climate } \\
\text { change-forestry issues such as forest inventory } \\
\text { and forest carbon accounting system, REDD+ } \\
\text { methodology, etc.; } \\
\text { Leading role in Indonesian delegation for the } \\
\text { UNFCCC REDD+ negotiation. }\end{array}$ & $\begin{array}{l}\text { Permenhut No. P68/Menhut- } \\
\text { II/2008 regarding REDD } \\
\text { Demonstration Activities; } \\
\text { Permenhut No. P.30/Menhut- } \\
\text { II/2009 regarding REDD } \\
\text { Permenhut No. P. 36/Menhut- } \\
\text { II/2009 regarding permits to } \\
\text { utilize carbon sinks in } \\
\text { production forests and } \\
\text { protected forests } \\
\text { REDD Indonesia (REDDI) } \\
\text { (produced by IFCA, 2008) }\end{array}$ & $\begin{array}{l}\text { These regulations and policy documents (REDDI) were the first } \\
\text { group of documents on REDD+ released by the Government } \\
\text { through the Ministry of Forestry. The regulations were still lacking } \\
\text { important details on REDD+ including financing, land tenure and } \\
\text { methodology,. Moreover, the regulations only rule out the REDD+ } \\
\text { components that are associated with the role and function of the } \\
\text { Ministry of Forestry because it cannot rule out the other ministries' } \\
\text { roles on REDD+ as those ministries are at the same level of } \\
\text { authority. } \\
\text { REDDI had been the only policy document to specifically discuss } \\
\text { REDD+. However, this document had also received less support } \\
\text { from other ministries. Even though the document preparation had } \\
\text { received strong support from several donors (both bilateral and } \\
\text { multilateral) and some international NGOs, the exclusiveness of } \\
\text { the REDDI process excluded several important agencies related to } \\
\text { REDD+ and they therefore gave less attention to this document. } \\
\text { As a result, REDDI had not been used as a policy document by the } \\
\text { government. Moreover, the Government through the UKP4 and } \\
\text { the REDD+ task force intends to develop a new policy document } \\
\text { so called the REDD+ National Strategy. }\end{array}$ \\
\hline
\end{tabular}


Attachment 1 (cont.)

\begin{tabular}{|c|c|c|}
\hline Institution, role and functions & $\begin{array}{c}\text { Climate change and REDD+ } \\
\text { related products }\end{array}$ & Brief comments and/ analysis \\
\hline $\begin{array}{l}\text { Presidential Working Unit on the } \\
\text { Development Control and Supervision } \\
\text { (Unit Kerja Presiden Bidang } \\
\text { Pengawasandan Pengendalian } \\
\text { Pembangunan/UKP4) }\end{array}$ & & \\
\hline $\begin{array}{l}\text { General Roles and Functions: } \\
\text { To ensure specific president development } \\
\text { targets during election campaign achieved and } \\
\text { in line with other sectoral targets; } \\
\text { Other specific tasks defined directly by the } \\
\text { President (Presidential Regulation no. 54/ } \\
2009 \text { about Presidential Working Unit on } \\
\text { Development Control and Supervision). } \\
\text { Roles and Functions in REDD+: } \\
\text { Coordinating Agency for REDD+ bilateral } \\
\text { agreement with the Norway Government. }\end{array}$ & $\begin{array}{l}\text { Establish REDD+ Task Force } \\
\text { Selecting the Central } \\
\text { Kalimantan Province as the } \\
\text { REDD+ National Pilot Project } \\
\text { In collaboration with the } \\
\text { REDD+ Task Force, prepare } \\
\text { draft of REDD+ National } \\
\text { Strategy and natural forest and } \\
\text { peat moratorium }\end{array}$ & $\begin{array}{l}\text { Up to the time when this paper was prepared, there was no public } \\
\text { policy document on REDD+ released by the UKP4 and its REDD+ } \\
\text { task force; however, their role is becoming stronger in coordinating } \\
\text { all REDD+ readiness and implementation. Their intention } \\
\text { (specified in the second draft of the REDD+ National Strategy) is to } \\
\text { support a few institutions to tackle problematic REDD+ issues such } \\
\text { as financing, MRV (monitoring, reporting, and verification), and } \\
\text { coordination, shows the UKP4's strong leadership on future } \\
\text { REDD+ readiness and implementation. Nonetheless, the } \\
\text { involvement of the UKP4 with its task force and its future REDD+ } \\
\text { institutions has created confusion on the future role of the line } \\
\text { ministries so far. }\end{array}$ \\
\hline \multicolumn{3}{|l|}{ BAPPENAS } \\
\hline $\begin{array}{l}\text { General Roles and Functions: } \\
\text { Coordinate the preparation of an integrated } \\
\text { national development plan, development } \\
\text { budget plan (Presidential Decree No.2/2002 } \\
\text { about the revision on Presidential Decree } \\
\text { No.101/2001 on Structure, Role, Function, }\end{array}$ & $\begin{array}{l}\text { The } 1^{\text {st }} \text { Yellow Book: } \\
\text { Indonesia’s response to Climate } \\
\text { Change (2007) } \\
\text { The } 2^{\text {nd }} \text { Yellow Book: } \\
\text { Indonesia's response to Climate }\end{array}$ & $\begin{array}{l}\text { BAPPENAS attempted to play a role in anticipating climate change } \\
\text { issues according to its original roles and functions. The Yellow } \\
\text { Book ( } 1 \text { and } 2) \text { demonstrated that BAPPENAS put effort into } \\
\text { coordinating the line agencies to prepare action plans for adaptation } \\
\text { and mitigation, including preparing the Indonesia climate change } \\
\text { funding mechanism through the ICCTF. Regrettably, the Yellow }\end{array}$ \\
\hline
\end{tabular}


Attachment 1 (cont.)

\begin{tabular}{|c|c|c|}
\hline Institution, role and functions & $\begin{array}{c}\text { Climate change and REDD+ } \\
\text { related products }\end{array}$ & Brief comments and/ analysis \\
\hline $\begin{array}{l}\text { Authority, Organization, and Management of } \\
\text { the State Ministers); } \\
\text { Act as the 'gate keeper' for any government } \\
\text { international development cooperation. } \\
\text { Roles and Functions in REDD+: } \\
\text { Integrate climate change plan into Mid-term } \\
\text { and Annual Development Plan, including all } \\
\text { aspects related to REDD++; } \\
\text { Create and oversight the management of the } \\
\text { Indonesia Climate Change Trust Fund } \\
\text { (ICCTF); } \\
\text { Leading role in Indonesian delegation for the } \\
\text { UNFCCC Financial Mechanism negotiation of } \\
\text { the UNFCCC. }\end{array}$ & $\begin{array}{l}\text { Change (revised) (2008) } \\
\text { Indonesia Climate Change } \\
\text { Trust Fund (ICCTF) (2009) } \\
\text { Indonesia Climate Change } \\
\text { Sectoral Road Map (ICCSR) } \\
\text { (2009) } \\
1^{\text {st Draft REDD+ National }} \\
\text { Strategy (December 2010) } \\
\text { Indonesia Action Plan on } \\
\text { Greenhouse Gas Mitigation } \\
\text { (RencanaAksi Nasional } \\
\text { Penurunan Emisi Gas Rumah } \\
\text { Kaca/ RAN-GRK) }\end{array}$ & $\begin{array}{l}\text { Books only ended up with a wish list of line ministries' project } \\
\text { proposals to engage in climate change context. There was no clear } \\
\text { support from the bilateral and multilateral donor agencies when all } \\
\text { those projects were offered. The donor agencies reactions were still } \\
\text { in 'wait and see' mode and waited for the results of COP15 in } \\
\text { Copenhagen. } \\
\text { The only follow up to these documents was the establishment of the } \\
\text { ICCTF which is still operating, supported by few bilateral donors } \\
\text { (United Kingdom, Germany, Australia). Among others, the Forestry } \\
\text { funding window including REDD+ financing was originally } \\
\text { intended to be the prime mover of the ICCTF; however, after the } \\
\text { involvement of the UKP4 and its intention to have a special } \\
\text { REDD+ trust fund for Indonesia-Norway bilateral cooperation, it } \\
\text { remains unclear whether REDD+ will be included in the ICCTF } \\
\text { scheme. } \\
\text { In order to support the preparation of the Mid-term National } \\
\text { Development Plan } 2010-2014, \text { BAPPENAS, together with line } \\
\text { ministries, prepared the ICCSR. However, the Forestry Sectoral } \\
\text { Road Map, which supposed to include a REDD+ road map, failed } \\
\text { to be presented due to complexities and non-synergistic policy } \\
\text { assessments among institutions. Nonetheless, the BAPPENAS had } \\
\text { received another task from the Economic Coordinating Minister to } \\
\text { prepare a National Action Plan on Greenhouse Gases Mitigation. In } \\
\text { the same time, it also received a task from the REDD+ Task Force } \\
\text { to prepare a National REDD+ strategy. While the RAN-GRK } \\
\text { (including Forestry Sector Emissions) had been submitted to the } \\
\text { Cabinet Secretariat for Presidential approval, the first draft REDD+ }\end{array}$ \\
\hline
\end{tabular}


Attachment 1 (cont.)

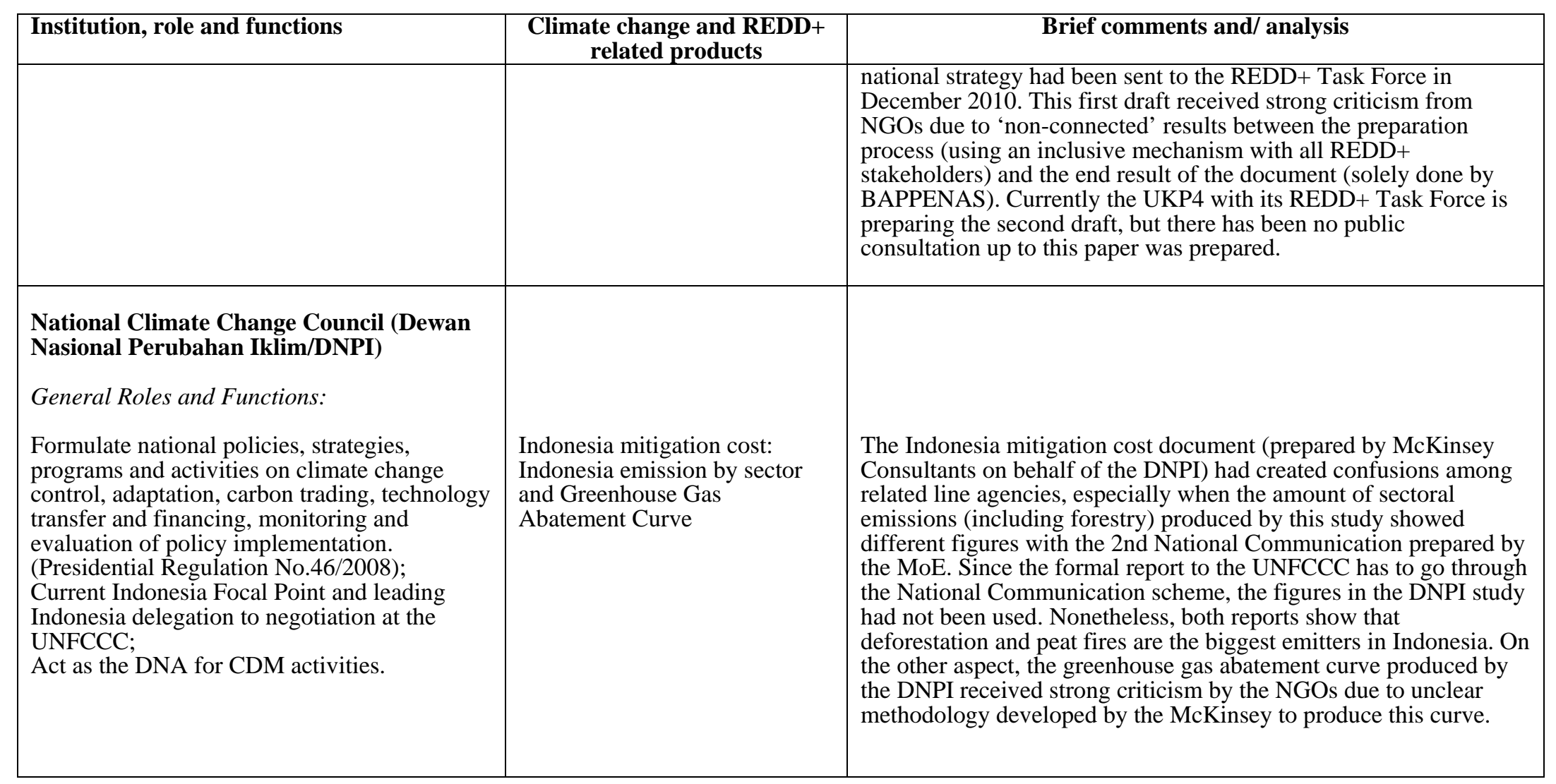


Attachment 1 (cont.)

\begin{tabular}{|c|c|c|}
\hline Institution, role and functions & $\begin{array}{c}\text { Climate change and REDD+ } \\
\text { related products }\end{array}$ & Brief comments and/ analysis \\
\hline $\begin{array}{l}\text { Ministry of Environment (MoE) } \\
\text { General Roles and Functions: } \\
\text { Policy development, coordinate and manage } \\
\text { all related maters to environmental impact and } \\
\text { management. (Presidential Decree No.2/2002 } \\
\text { about the revision on Presidential Decree } \\
\text { No.101/2001 on Structure, Role, Function, } \\
\text { Authority, Organization, and Management } \\
\text { of the State Ministers). } \\
\text { Roles and Functions in REDD+: } \\
\text { The MoE did not have specific role in } \\
\text { REDD+, rather it had a special role in } \\
\text { coordinating climate change issue before this } \\
\text { role was taken over by the DNPI in 2009; } \\
\text { Compiling and coordinating the preparation of } \\
\text { the National Communications to the } \\
\text { UNFCCC, including the Forestry sector; } \\
\text { Act as the Designated of National Authority } \\
\text { (DNA) for the CDM until 2009. The role of } \\
\text { DNA was handed over to DNPI in 2009. }\end{array}$ & $\begin{array}{l}\text { National Action Plan on } \\
\text { Climate Change Mitigation and } \\
\text { Adaptation/ } \\
\text { RencanaAksiNasionalMitigasi } \\
\text { and AdaptasiPerubahanIklim/ } \\
\text { RAN-MAPI (2007) } \\
1^{\text {st }} \text { National Communication to } \\
\text { the UNFCCC (2005) } \\
2^{\text {nd }} \text { National Communication to } \\
\text { the UNFCCC (2009) }\end{array}$ & $\begin{array}{l}\text { The RAN-MAPI document was the first integrated climate change } \\
\text { action plan document released by the government. The forestry } \\
\text { sector's emissions and the plan to reduce them were analyzed and } \\
\text { presented in this document. During COP } 13 \text { in } 2007 \text { in Bali, this } \\
\text { document was supposed to be a reference document for the } \\
\text { Indonesian delegation. However, at that time, this document } \\
\text { received less support from other line ministries as most of them } \\
\text { questioned the role of the MoE to coordinate all this action plans, } \\
\text { which were mostly related to development plans. There had been no } \\
\text { follow up of the RAN-MAPI. } \\
\text { The National Communication, in particular the Second stage, } \\
\text { showed a strong role for the MoE in the climate change policy } \\
\text { debate. In the 2 2d National Communication, the MoE compiled all } \\
\text { emission reports from the line sectoral ministries and presented this } \\
\text { to the UNFCCC. The MoE concluded that the forestry sector, } \\
\text { especially due to deforestation and peat fires, is the largest emitter. } \\
\text { Since its coordinating role in climate change was transferred to the } \\
\text { DNPI, the MoE has not produced any national climate change } \\
\text { documents. }\end{array}$ \\
\hline
\end{tabular}

